\title{
UDC 351.82:[37.014.6:005.6]
}

Yaremenko Natalia Volodymyrivna, PhD of philological sciences, Kryoyi Rih, State Pedagogical University, 50086, Kryvyi Rih, Prospect Haharina, 54, tel.: +38 (067) 56430 08, e-mail: yartala28@gmail. com

ORCID: 0000-0003-2834-0894

\section{Яременко Наталя Володимирівна,}

кандидат філологічних наук, доцент, ДВНЗ "Криворізький державний педагогічний університет", 50086, м. Кривий Ріг, просп. Гагаріна, 54, тел.: +38 (067) 564 30 08,e-mail:yartala28@gmail.com

ORCID: 0000-0003-2834-0894

\section{Яременко Наталья Владимировна,}

кандидат филологических наук, дочент, ГВУЗ "Криворожский государственный педагогический университет”, 50086, 2. Кривой Рог, просп. Гагарина, 54, тел.: +38 (067) 56430 08, e-mail: yartala28@ gmail.com

ORCID: 0000-0003-2834-0894

\section{Kolomiets Natalia Yevhenivna,}

PhD of philological sciences, Kryoyi Rih State Pedagogical University, 50086, Kryvyi Rih, Prospect Haharina, 54, tel.: +38 (067) 940 08 14, e-mail:natagh2012@ukr.net

ORCID: 0000-0001-5455-2538

\section{Коломієць Наталія Свгенівна,}

кандидат філологічних наук, доиент, ДВНЗ "Криворізький державний педагогічний університет”, 50086, м. Кривий Ріг, просп. Гагаріна, 54, тел.: +38 (067) 564 30 08,e-mail:yartala28@gmail.com

ORCID: 0000-0001-5455-2538
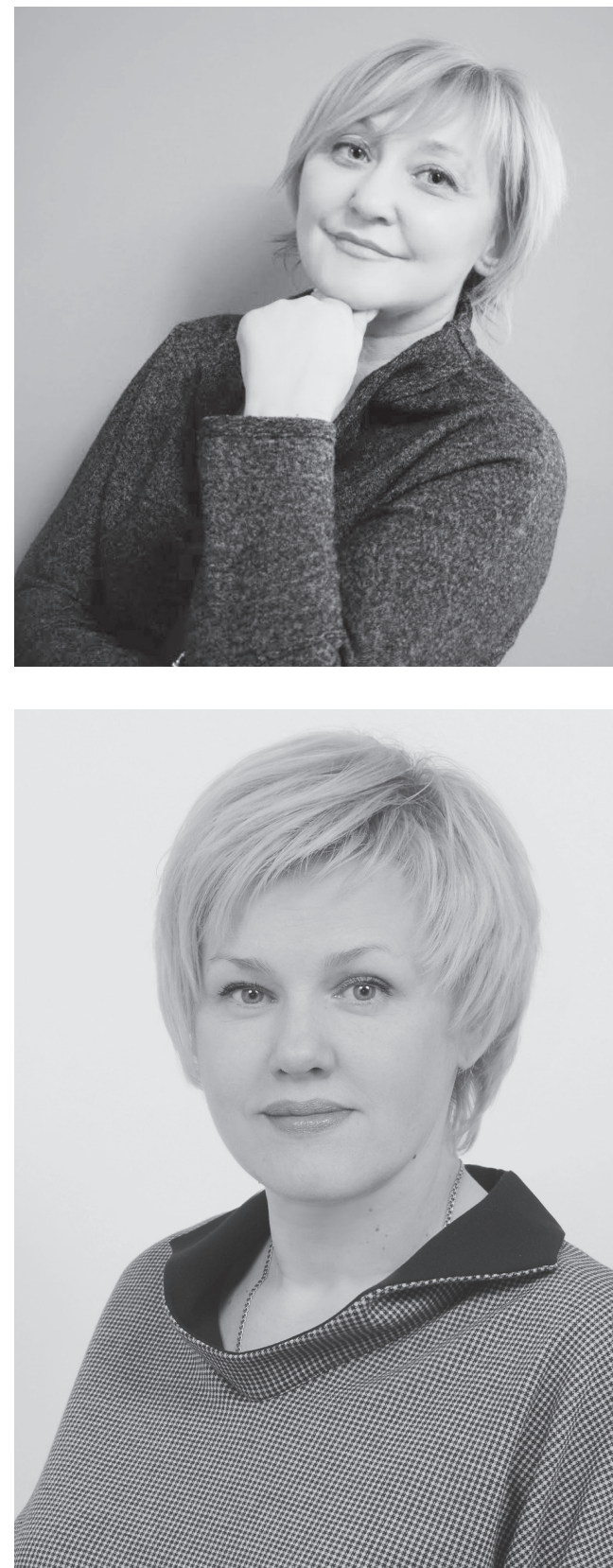

\section{Коломиещ, Наталия Евгеньевна,}

кандидат филологических наук, доцент, ГВУЗ “Криворожский государственный педагогический университет", 50086, г. Кривой Рог, просп. Гагарина, 54, тел.: +38 (067) 564 30 08,e-mail:yartala28@gmail.com

ORCID: 0000-0001-5455-2538

DOI https://doi.org/10.31618/vadnd.v1i14.126 


\section{REINTERPRETATION OF THE ARCHETYPES OF THE "DIVINE CHILD" IN THE ASPECT OF THE IMPLEMENTATION OF THE SUSTAINABLE DEVELOPMENT PROGRAM}

Abstract. The article makes an attempt to clarify the specifics of the reinterpretation of the "Divine Child" archetype in the aspect of implementing the Sustainable Development Program adopted in September 2015 by the decision of the UN General Assembly. The main ways of overcoming the current crisis of education are identified through the formation of new mental invariants of the basic first elements of culture through clarifying the meanings of archetypes, the formation of new layers and the production of values. It is suggested that such reinterpretation is a significant step towards creating a balanced model of the global community, since the reorientation of the paradigm of public consciousness necessitates the reform of the education system. Actualization of the "Divine Child" archetype in the aspect of implementing the Sustainable Development Program demonstrates the modification of the cultural heritage of mankind in a global society. The child, however, is the archetypal foundation of the very first being. The transformation of the original archetype into the modern life flow is due to value orientations, mental structures, religious-spiritual concepts and socio-cultural requirements of the day. The authors emphasize that the semantic center of comprehension of the problem of childhood is the archetype "Divine Child", which acts as a matrix of collective unconscious experience and is realized in reality. In the article it was found, in particular, that, regardless of the cultural orientations of the age, the semantic center of childhood is based on the understanding that the younger generation is carrying out a renewal of life and in the future will form a new world order. Therefore, it is necessary to transfer education from simply reproducing knowledge and skills to the competencies necessary for existence in a modern dynamic society.

Keywords: archetype, divine child, Puer, Sustainable development program, mental invariant.

\section{РЕІНТЕРПРЕТАЦІЯ АРХЕТИПУ “БОЖЕСТВЕННА ДИТИНА” В АСПЕКТІ РЕАЛІЗАЦЇ̈ ПРОГРАМИ СТАЛОГО РОЗВИТКУ}

Анотація. Розглянуто специфіку реінтерпретації архетипу “божественна дитина” в аспекті реалізації Програми сталого розвитку, ухваленої у вересні 2015 року рішенням Генеральної Асамблеї ООН. Виявлено основні шляхи подолання сучасної кризи освіти шляхом формування нових ментальних інваріантів базових першоелементів культури, через уточнення смислів архетипів, формування нових пластів, продукування цінностей. Подібна реінтерпретація є вагомим кроком на шляху до утворення збалансованої моделі глобального співтовариства. Переорієнтація парадигми суспільної свідомо- 
сті зумовила потребу реформувати систему освіти, адже потенціал майбутнього формується у процесі становлення особистості дитини. Актуалізація архетипу “божественної дитини” в аспекті реалізації Програми сталого розвитку демонструє модифікацію культурного надбання людства в глобалізованому соціумі. Акцентовано, що смисловим центром осягнення проблеми дитинства є архетип “божественної дитини”, який виступає матрицею колективного безсвідомого досвіду та актуалізується й об'єктизується в реальному бутті, оскільки процес формування дорослої людини дає змогу розглядати дитинство як унікальну соціокультурну цінність, коли закладаються підвалини майбутнього. Дитина ж є архетипною основою першопочатку буття. Трансформація первісного архетипу в сучасний життєвий потік відбувається завдяки ціннісним орієнтирам, ментальним структурам, релігійно-духовним концептам та соціокультурним вимогам доби. Спостережено зокрема, що незалежно від культурних орієнтирів доби, смисловий центр дитинства базується на розумінні того, що молоде покоління продукує оновлення буття, і в майбутньому формуватиме новий устрій. А отже потребує переходу освіти від простого репродукування знань і навичок до компетенцій, необхідних для існування в динамічному сучасному.

Ключові слова: архетип, божественна дитина, Пуер, Програма сталого розвитку, ментальний інваріант.

\section{РЕИНТЕРПРЕТАЦИЯ АРХЕТИПА “БОЖЕСТВЕННОЕ ДИТЯ" В АСПЕКТЕ РЕАЛИЗАЦИИ ПРОГРАМЫ УСТОЙЧИВОГО РАЗВИТИЯ}

Аннотация. Рассмотрена специфика реинтерпретации архетипа “божественный ребенок” в аспекте реализации Программы устойчивого развития, принятой в сентябре 2015 решением Генеральной Ассамблеи ООН. Выявлены основные пути преодоления современного кризиса образования путем формирования новых ментальных инвариантов базовых первоэлементов культуры, через уточнение смыслов архетипов, формирование новых пластов, продуцирования ценностей. Подобная реинтерпретация является весомым шагом на пути к образованию сбалансированной модели глобального сообщества, поскольку переориентация парадигмы общественного сознания обусловливает необходимость реформирования системы образования. Актуализация же архетипа “божественного ребенка" в аспекте реализации Программы устойчивого развития демонстрирует модификацию культурного наследия человечества в глобальном социуме. Акцентировано, что смысловым центром постижения проблемы детства является архетип "божественного ребенка”, который выступает матрицей коллективного бессознательного опыта и реализуется в реальности, поскольку процесс формирования взрослого человека позволяет рассматривать детство как уникальную социокультурную ценность, когда закладываются основы будущего. Ребенок же является архетипной основой истока бытия. Трансформация первоначального архетипа в современный жизненный поток происходит благодаря цен- 
ностным ориентирам, ментальным структурам, религиозно-духовным концептам и социокультурным требованиям времени. Обнаружено в частности, что независимо от культурных ориентиров эпохи, смысловой центр детства базируется на понимании того, что молодое поколение производит обновление бытия, и в будущем будет формировать новый миропорядок. Следовательно, требует перехода образования от простого репродуцирования знаний и навыков в компетенции, необходимые для существования в современном динамичном социуме.

Ключевые слова: архетип, божественный ребенок, Пуэр, Программа устойчивого развития, ментальный инвариант.

Statement of the problem. The crisis that the modern world is facing, requires the development and implementation of systematic action to preserve the earth and humanity from the real threats. That is what prompted to actively seek ways to overcome the systemic crisis. In September of 2015, according to the decision of the UN General Assembly a Sustainable Development Program was adopted, which contains objectives that define the general direction of world development, and is the basis of international efforts for joint activities for the preservation and restoration of the world's resources. These seventeen areas determine the fundamentals of the interaction of states at all levels of development for the next fifteen years and describe all aspects of human activity (economy, social life, political processes, environmental preservation, etc.). The leading position of sustainable development was developed in the process of the UN conference on environment and development in 1992 (Rio de Janeiro), modified at the World summit in Johannesburg (2002), fleshed out and finalized at the conference "Rio +20 " in 2012. In addition, in September of 2017 the government of Ukraine presented the report "Sustainable Development Goals: Ukraine”, which defined leading parameters of SDP implementation to meet the needs of today without destroying the opportunities of future generations, taking into account the specifics of national development.

One of the central problems to be solved by the Sustainable Development Program is to ensure inclusive and equitable quality education, promote the creation of learning opportunities throughout life, that is, the creation of new educational environment that would allow to change the stereotypes of thinking and behavior, to upgrade the human community, create the foundation for change and to contribute to the realization of the leading concepts of sustainable development. "We are committed to provide quality educational activities at all levels early childhood, elementary, secondary, higher, technical and vocational training. All people, regardless of gender, age, race, ethnicity and people with disabilities, migrants, indigenous peoples, children and youth, especially those in vulnerable situations should have access to learning opportunities through- 
out life that will help them to obtain the knowledge and skills required to use the opportunity to fully participate in society. We will attempt to provide children and young people with favorable conditions for the full implementation of their rights and opportunities, helping our countries to benefit from the demographic dividend, including through the safe schools and the joint communities and families" [1, p. 22]. There can be no doubt that education is at the center of the spiritual system as a potential generated on the basis of the Jungian concept of the archetype of the "Divine child" which is simultaneously the source of moral existences.

The education crisis, which manifested itself at the present stage, is considered in the context of global problems of modernity along with demographic, environmental and economic ones; it requires a comprehensive approach, since the world faces a real threat for several decades to form a fully illiterate generation. In this regard, the UNESCO world conference on ESC, held in Aichi-Nago (Japan) in 2014, provided the assessment of the current state of education and developed a concept aimed at the implementation of educational reform for achieving sustainable development.

According to the data given by Amel Karbul, a member of the International Commission on financing opportunities in education on a global level, "if the leaders now do not take action to increase investment and reforming the world of education, more than 124 million young people will lack access to schools and more than 250 million will not be able to obtain the skills necessary for a healthy and successful life" [2].
Analysis of recent researches and publications. In contemporary scientific discourse the problem of the reinterpretation of the archetype of the "Divine child" in the aspect of implementation of the Sustainable Development Program is considered on the verge of humanitarian studies, anthropological and political directions. Various aspects of the program were the subject of research in many works of researchers, in particular the regulation of international relations is considered in the works of D. Medows, G. Gardner, N. Carter, and others; the challenges of globalization in the context of implementing sustainable development programs were studied by D. Korten, C. Flavin and A. Ursula; the criteria for crisis-free economic development were developed in the works of V. Rostow; ecocentric paradigm was implemented in the research of M. Redclif, L. Milbright, I. Randers and the like.

The purpose of this article is to clarify the specifics of reinterpretation of the archetype of the "Divine child" in the aspect of realization of the Sustainable Development Program as a means of overcoming the educational crisis.

Presentation of the basic material. The changes occurring in recent decades, led to a reorientation of values in society and influenced the formation of new mental invariants of the underlying elements of culture. First of all, we are talking about the clarification of the meanings of the archetypes, the formation of new segments and production values. This reinterpretation is an important step on the way to the formation of a balanced pattern of global community. The reinterpretation of the paradigm of social consciousness ne- 
cessitated the reform of the education system, because the potential future is formed in the process of developing the child's personality. "The increased interest of the Humanities to the theme of childhood at the turn of XX-XXI centuries gave it the status of the interdisciplinary problems, which led to the possibility and necessity to consider the data of physiology, psychiatry, psychoanalysis, ethnography, ethno-psychology, pedagogical psychology and law, and special studies of childhood. However, the recognition of the interdisciplinary nature of the problem has not yet developed an awareness of the availability of discursive unity of childhood and, especially, to the designation of the external and internal boundaries of this unity" [3, p. 7]. The prospect of the constructive design of the future, productive advancement of humanity to the establishment of harmonious relationships becomes possible with the harmonization of the spiritual and value spaces where the regulatory role belongs to archetypes.

Actualization of the archetype of the "Divine child" in the aspect of implementation of the Sustainable Development Program shows the transformation of the cultural experience of mankind in modern globalization processes. Projection of metaconcepts on modern life leads to the manifestation of axiological and conceptual universe of man's future. K. G. Jung stated: "All mythology and all revelations come from this matrix of experience and, consequently, future idea about the world and man will come out of it" [4, p. 219246.]. According to the teachings of K. G. Jung, one of the biggest archetypical characteristics is the projec- tion for the future. The peculiarities of intellectual and psycho-physical development of children determine such traits as naivety, dependence on the opinion of adults, openness, mental clarity etc.

The process of forming an adult allows us to consider childhood as a unique socio-cultural value, when the foundation is laid for the future. L. Nefedova determines the immanent and the continuum as a philosophical basis of the representation of childhood: "The meaning of immanent is absolute, the one, the self; the sense of the continuum is the establishment in the genesis of the self, separation and its formation. A baby, being a pure inseparability, in keeping its self's divinity and unity with the absolute, rooted in genesis, carries out the separation of the self, being differentiated, and this affects continuity. The most intense expression of continuity is the border between childhood and adulthood" [3, p. 12]. The process of identity formation is based on archetypical situations, rooted in genesis. Accordingly, the child appears not only as a phenomenon, but with the prospect of adaptation to adult life, with increased possibilities of the child in understanding the processes of the universe, the formation of its queries and interests occurs with the loss of the feeling of integrity and harmony of existence.

The child is the archetypical basis the source of being. The transformation of the initial archetype in modern life flow occurs due to the values and mental structures, religious-spiritual and socio-cultural concepts to the requirements of the day. Social public policy in the interests of children at 
the present stage can be represented in the following aspects: the protection of children's rights, child protection, education, social protection etc. As claimed by T. Kovalenko, "from 1991 at the legislative level in Ukraine the following principles were rooted: priority of interests of the child; ensuring the full life of the children; children's involvement in community life and the proclamation of the absence in Ukraine of all forms of discrimination against children" [5, p. 109]. This thesis confirms the idea that all the weighty moral and ethical ideas that are formed in society, are rooted in archetypes.

The provisions of the Sustainable Development Program concerning the educational process, reveal the value potential and the higher meaning of the content of the phenomenon of childhood. At this angle issues of gender identity, informational interactions of individuals, society and nature, the formation of a critical, innovative and creative approach to finding solutions to pressing issues of our time seem to be extremely important. Current needs for educational activities are reasoned by the paradigm according to which the child that is crossing the line of growing up, needs to be adapted to the dynamic and changing world, focused on the universe, endowed with creative ability to combine different types of activities, self-improvement and selfdevelopment.

In addition, the formulation of the problem of gender identity of boys and girls in childhood should affect the inequality of genders in society and strengthen future participation of women in social, economic and political life of society. The educational sys- tem now has a powerful pedagogical potential, aimed at the formation with the younger generation of the principles of gender equality and gender appropriate behavior, which involves the elimination of the various manifestations of discrimination, formation of respect for the individual irrespective of the gender and of equal position of both genders in society. "The gender approach in pedagogy suggests a move away from the concept of "innate" sexual differences between boys and girls in the educational ideas of innate gender roles, focuses on the institutional aspect of the environment and the context of interaction of subjects of gender relations. Gender approach in education is expressed in the rejection of the asymmetry of gender socialization of the binary type and the transition to a multipolar model of the social construction of gender without distribution of reproductive differences on all other areas of life for women and men. The main strategy of gender approach in education is encouraging children to greater flexibility in behavior, interests and personality traits compared with the framework of gender roles; the creation of such educational environment, in which the feminine and masculine in each person will be developed as two interrelated dimensions of any personality and are integrated into psychological androgyny" [6, p. 122]. It is assumed that the involvement of women on equal terms with men to the management of resources, processes of economic planning and decision-making will lead to a departure from the asymmetry of social roles of women and men in the society, will approve the establishment of partnerships in the family 
and will harmonize the various spheres of human activity.

Aspect of information interaction of the individual, society and nature, is aimed primarily at improving the environmental situation, development of strategies to tackle climate change, improvement of the environmental condition by reducing emissions of greenhouse gases, etc. Covering these problems in the educational process is the initial stage of transformation of public thought on the way to sustainable development.

Under the terms of the formation of a critical, innovative and creative approach to finding solutions to pressing issues of our time in a generation that is being formed, it will affect the vectors of social development and perform culture-formatting function in a new type of thinking. Modern man since childhood is focused on constant learning as the ability to adapt to new demands of civilization. This is facilitated by the rapid change of technology, the informatisation of all spheres of public life, economic and sociocultural globalization, and the like.

"The Agenda for XXI century" priorities for modernization of education for sustainable development. In particular, it noted that basic secondary education requires improvement as the nations which have high levels of illiteracy and predominantly unskilled labor, have little hope for sustainable development. In addition, the existing education should refocus the content and methodology to the implementation of the leading challenges of sustainable development, and therefore to build new teaching system, integrating the problems of economy, ecology and society in a single system. It so emphasized that the man of the future must possess a number of competencies focused on the environmentally sound management, and active participation in society and a healthy lifestyle.

Conclusions. Consequently, the actualization of the archetype of the "Divine child" in the aspect of implementation of the Sustainable Development Program demonstrates the modification of the cultural heritage of humankind in a globalizing society. The focal point of understanding the problems of childhood is the archetype of the "Divine child", which is the matrix of the collective unconscious experience and is objected in real life. Regardless of the cultural landmarks of the era, the semantic childhood center is based on the understanding that the young generation produces updates of being and in the future will generate new, not previously existing system. At the present stage the rethinking of the educational paradigm with the aim of implementing of Sustainable Development Program takes place, and this requires the education transition from simple reproduction of knowledge and skills to competencies required for existence in the modern dynamic world.

\section{REFERENCES}

1. Transforming our world: the 2030 Agenda for Sustainable Development (n.d.). sustainabledevelopment.un.org. Retrieved from https://sustainabledevelopment.un.org/post2015 [in English].

2. About the Education Commission (n.d.). educationcommission.org. Re- 
trieved from http://educationcommission.org/about/ [in English].

3. Nefedova L. K. (2005). Fenomen detstva $\mathrm{v}$ osnovnykh formakh ego reprezentatsii (filosofiya, mif, folklor, literatura) [The phenomenon of childhood in the main forms of its representation (philosophy, myth, folklore, literature)]. Doctor's thesis. Omsk [in Russian].

4. Jung C. G. (1996). Analiticheskaya psikhologiya i mirovozzrenie [Die Analytische Psychologie und Weltanschauung]. Problemy dushi nashego vremeni - Seelenprobleme der Gegenwart. Moscow: Izd. gruppa "Progress", Univers [in Russian].

5. Kovalenko T. (2014). Dytyna yak obiekt derzhavnoho upravlinnia u sferi sanatorno-kurortnoho zabezpechennia [The child as an object of public administration in the sphere of sanatorium and resort provision]. Derzhavne upravlinnia ta mistseve samovriaduvannia - State administration and local self-government, 2 (21), 108-118 [in Ukrainian].

6. Svitailo N. (Ed.). (2013). Formuvannia u molodi henderno-vidpovidalnoi povedinky (na prykladi ukrainskykh VNZ) [Formation of gender-responsive behavior among young people (on the example of Ukrainian universities)]. Sumy : Vyd-vo RA "Khoroshye liudy" [in Ukrainian].

\section{СПИСОК ВИКОРИСТАНИХ ДЖЕРЕЛ}

1. Transforming our world: the 2030 Agenda for Sustainable Development [Електронний ресурс]. - С. 22. Режим доступу: https://sustainabledevelopment.un.org/post2015

2. Про освітню комісію [Електронний pecypc]. - Режим доступу: http:// educationcommission.org/about/

3. Нефедова Л. К. Феномен детства в основных формах его репрезентации (философия, миф, фольклор, литература) : автореф. дис. ... д-ра филос. наук : 09.00.13 / Л. К. Нефедова. - Омск, 2005. - 38 с.

4. Юнг К. Г. Аналитическая психология и мировоззрение / К. Г. Юнг // Проблемы души нашего времени. М. : Изд. группа “Прогресс", 1996 ; Универс, 1996. - 331 с.

5. Коваленко Т. Дитина як об'єкт державного управління у сфері санаторно-курортного забезпечення / Т. Коваленко // Держ. упр. та місцеве самоврядування: зб. наук. пр. / гол. ред. С. М. Серьогін. - Дніпропетровськ: ДРІДУ НАДУ, 2014. Вип. 2 (21). - С. 108-118.

6. Формування у молоді гендерно-відповідальної поведінки (на прикладі українських ВНЗ) : навч. посіб. / за заг. ред. Н. Світайло. - Суми : Хорошие люди, 2013. - 209 с. 